\title{
Succession: The Next Ones at Bat
}

\author{
William M. Curran
}

Throughout North America, more than 83,866 librarians will soon reach the age of 65 and will be taking, or plan to take, retirement. The exodus of practicing librarians will result in a severe shortage. With the departure of the older baby boomers, a serious collective loss is imminent in terms of experience and expertise because there are few experienced, trained, middle-level managers, supervisors, and administrators within the "middle" age group of librarians who could ensure appropriate succession in the libraries following such a massive retirement exodus.

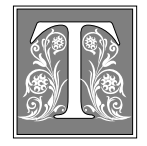

\section{he Aging Workforce Reality Check}

It is estimated that over the next eight years (i.e., by 2010),

Canadian universities will be seeking to recruit approximately 30,000 new faculty. ${ }^{1}$ Not since the early baby boomers first entered elementary schools in the early $1950 \mathrm{~s}$, and later when that same group proceeded into North American universities in the mid-1960s, has there been such a need for an influx of new faculty. The competition promises to be stiff. Issues such as status, benefits, salaries, sabbatical leaves, and so on will weigh heavily in scholars' decisions to accept tenure-tract positions in universities. In a paper presented to the Canadian Economics Association meeting in Montreal last summer, Dr. Paul Davenport warned that faculty retirements over the next decade will be very high as the cohort hired for the first baby boom retires. ${ }^{2}$ Universities will have to double their current annual hiring levels in order to maintain current faculty-student ratios at a time when (1) the United States will be competing for the same hiring pool, (2) Ph.D. enrollments have not expanded in pro- portion to the need in either country, and (3) demand for Ph.D.'s outside universities has increased in response to the needs of the knowledge economy.

Academic libraries will face exactly the same ordeal in recruiting librarians. Indeed, Quebec's Corporation of Professional Librarians (http://www.cbpq.qc.CA/corporation/profil_membres2000.html) is alerting its members that 20 percent of the current membership has already reached the age of 55. The oldest baby-boomer librarians will thus be approaching retirement within the next five to eight years.

James Matarazzo, dean of the Library School at Simmons College, warns that by $2010,83,866$ professional librarians will have reached the age of 65 and will be taking, or plan to take, retirement. ${ }^{3}$ The exodus of practicing librarians will result in an inevitable shortage that could prove critical. It is important to note furthermore that Dr. Matarazzo's figures exclude those librarians who will leave the profession to pursue other careers, as happens in the normal course of events, nor does it take into account other forms of attrition, such as illness and death. Stanley Wilder, the University of Rochester's assistant dean,

William M. Curran is Director of Libraries at Concordia University; e-mail: wcurran@alcor.concordia.ca. 
states that over the next fifteen years, 50 percent of librarians in Canadian ARL libraries will be retiring. And librarians are substantially older than those in comparable professions. Only 12 percent of librarians are in the 25 to 34 age range compared to 25 percent in that range in comparable professions. ${ }^{4}$

In 2001, Quebec's Corporation of Professional Librarians chose as its theme for the annual conference, Société cherche bibliothécaire désespérément. Desperation? Perhaps, but one must ask how the profession reached this point.

\section{Hiring, Retention, and Development}

In one academic library recently surveyed, 84 percent of the professional staff are over the age of 40 , and 55 percent are over the age of $50 .{ }^{5}$ Only three percent of librarians are between the ages of 20 and 30. In another academic library, 78 percent of the librarians are over age 40 . In a third academic library, it was found that 68 percent of professional staff are older than 50 years of age and 44 percent are older than 55 (half of whom are presently occupying management or "leadership" positions). ${ }^{6}$ Considering those eligible for retirement, apart from any "early" retirement packages, these libraries could lose half their senior professional staff within a given year. More significant, there are very few experienced, trained, middlelevel managers, supervisors, and administrators within the "middle" age group of librarians (40 to 50 years of age), who could ensure appropriate succession in the libraries in the event of a massive retirement exodus. An acute shortage of professional librarians will likely be felt at these levels, as well as at the entry level. It is not too surprising that the University of Manitoba Libraries' Task Force on Recruitment and Retention recommends that its director, or a designate, participate in CLA and ACRL job fairs. ${ }^{7}$

There are many reasons for this. For the past fifteen years, academic libraries have faced major budget cuts, which were not limited to collections but extended to staff positions as well. Many middle man- agement positions were abolished when they became vacant, not because the positions were not needed, but purely as cost-saving measures.

According to CARL Statistics, Table II shows that during a 6-year period, between 1993 to 1999 , the national average of administrative librarians decreased from 16.96 to 14.04. The Quebec provincial average for the same period went from 16.50 to $13.33 .^{8}$

Indeed, one hidden aftereffect of the cuts to supervisory and middle management positions in academic libraries has been an obstruction of the "natural" progressive promotion conveyor belt for librarians leading to senior administrative positions. Consequently, there have been few, if any, opportunities for progressive moves into increasingly responsible supervisory positions for an entire middleaged group of career-tract academic librarians. The careers of many academic librarians who, in the mid- to late $1980 \mathrm{~s}$, should have been moving into supervisory and middle management positions were effectively "arrested" as these types of management positions were merged and/or abolished.

The impact of a sudden, massive retirement of librarians who have administrative experience could be disastrous. The situation is not unique to any one academic library, so the chances of finding suitably experienced candidates from elsewhere to fill these managerial vacancies are slim.

As far back as 1994, 82 percent of library directors among the ARL membership were between 45 and 69 years of age. Between 1990 and 1994, the percentage of the population aged 55 and over went from 25.5 percent to 43 percent. ${ }^{9}$

The study conducted by Peter Hernon, Ronald R. Powell, and Arthur P. Young aims to: (1) determine succession; (2) identify those skills and competencies required of future directors; and (3) identify career paths and provide avenues for attaining senior administrative positions. It is im- 


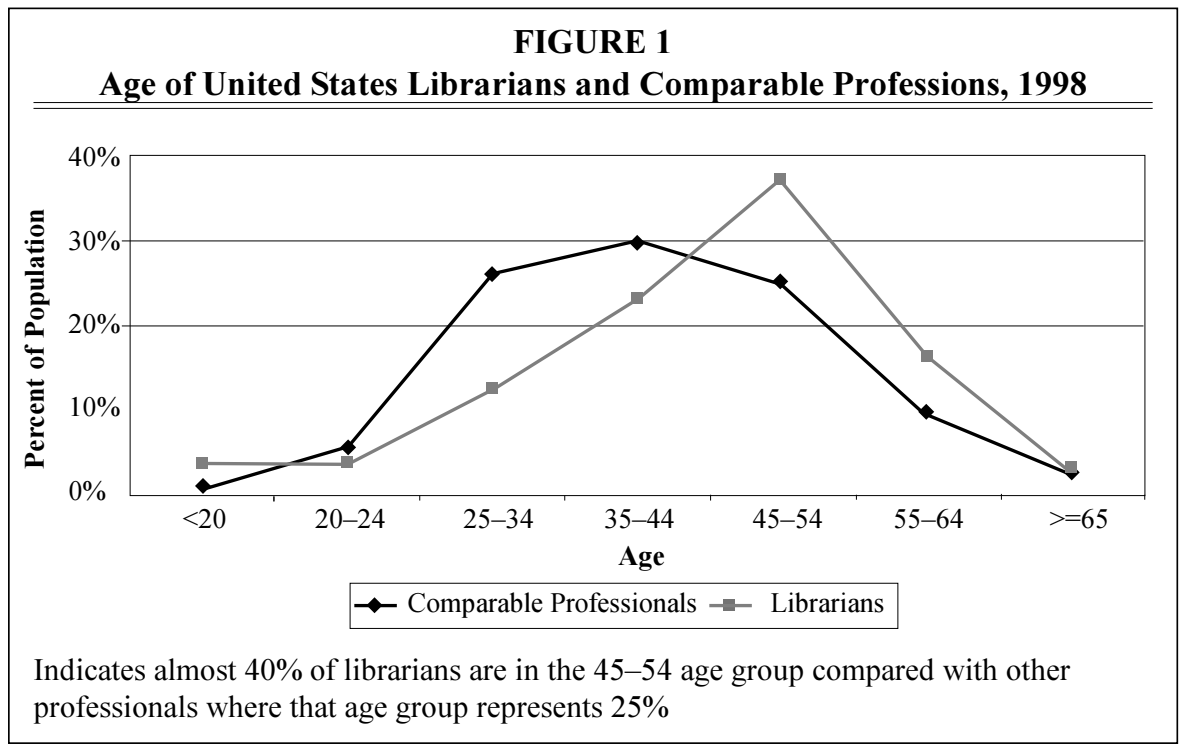

portant to note that the paths that enabled those who are now senior administrators to attain their positions will not automatically be the same - or appropriate-ones that will lead to the senior administration positions of tomorrow. Conditions change. As with every other professional library position (e.g., cataloguer, reference librarian, etc.), those skills required fifteen or twenty years ago that paved the way for today's directors may or may not be needed for library administration positions in the future. Be that as it may, one common denominator that will remain indispensable for senior administrators is prior management experience. The best example of poor succession planning is promoting a good technician into a

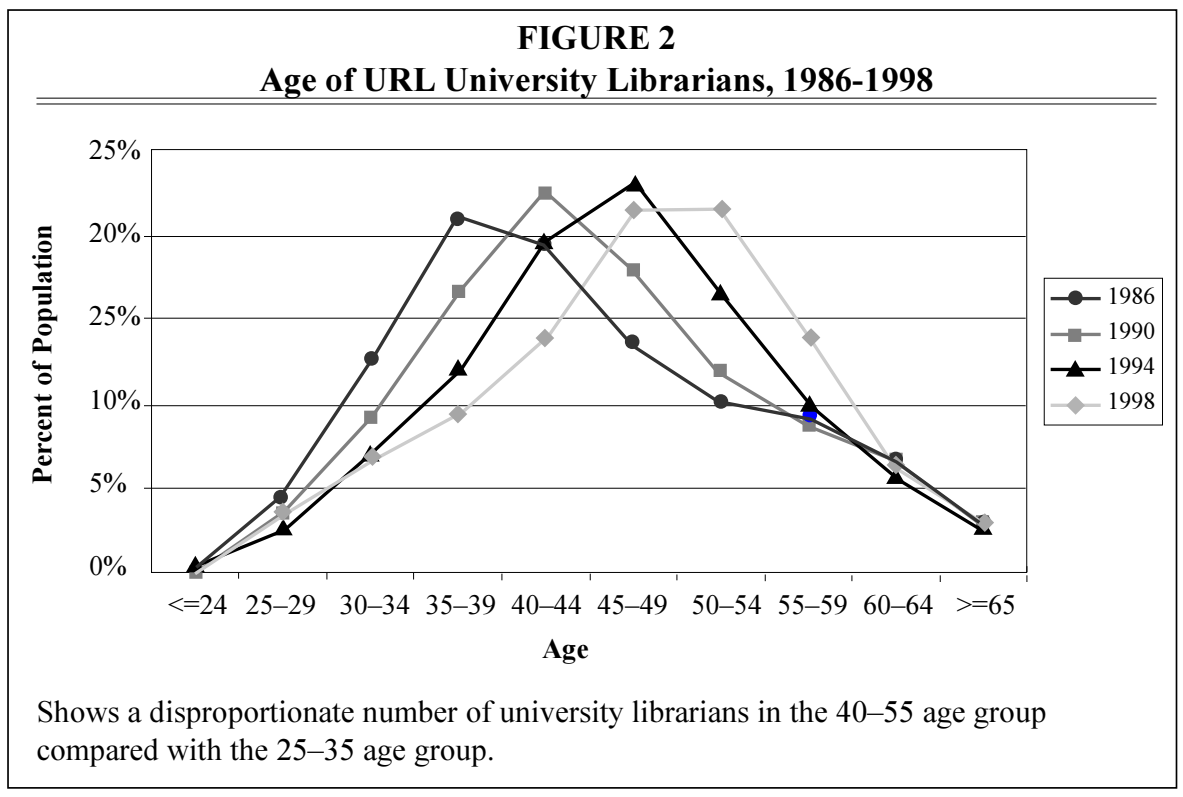


manager's position. Similarly, in a library setting, it would be difficult to imagine a scenario where an incumbent is "parachuted" into a senior administration position without appropriate management experience, acquired at progressively responsible stages of one's career. To add to this mix, Hernon, Powell, and Young point out:

The challenge of replacing retiring directors is increased by the rather small size of the pool of academic librarians qualified to be directors of large academic research libraries and by the fact that a number of qualified librarians are not interested in becoming directors of such libraries. ${ }^{10}$

Regardless of the organization, succession is a fundamental administrative component of planning. As vital to a vision of where the organization is-where it is going, when, and the impact of changes, service, products, and so on-is the element of who will lead it in the future and who is presently being trained to direct it and thus ensure its continuity.

This may not have been such an important question in the past. Library managers and administrators assumed, often correctly, that some assistant or secondin-command could "fill in" when the time came for the organization to seek a successor for a retiring administrator. Succession planning was relatively simple as long as there was a pool of competent applicants-or a potential for such. However, academic libraries have undergone enormous cuts, which extended over a period of fifteen years. The cuts to the acquisitions budgets were merciless, and collections will never "catch up" or "restock" despite infusions of so-called rattrappage moneys or of one-fell-swoop efforts to replenish the bare cupboards of research collections. That train has left the station. But the impact of fifteen years of cuts extends beyond collections to the expertise of professional librarians. In academic libraries, this became the practice: Vacant positions were either abol- ished on a routine basis or filled "internally." Annual academic library staff reductions were rampant. If a position became vacant through attrition, it was not filled but, rather, put on hold (temporarily) until a suitable time, such as when the next budget was decreed or when the position could be abolished. More often than not, this was welcome news because it meant no one would be laid off. Those who willingly left their positions were seen as doing a favor for those who remained. Supervisory and middle management positions that became vacant were "fused" or "merged" with other existing positions. This served to reduce the salary mass as well as the number of supervisors/managers in the library. It was almost routine to expect unit heads and supervisors to undertake additional workloads, sometimes doubling the original volume, and to supervise more staff, either on a temporary basis or permanently, occasionally, with a concession that a lower-level, part-time position be created. Often labeled under the rubric "organization reengineering," the practice drastically reduced the number of middle management positions to which academic librarians could ascribe, but it also discouraged those already filling middle management positions from progressing into more senior positions with additional responsibilities. With little opportunity for "advancement," low morale prevailed. Through no fault of their own, academic librarians thus reached a "plateau" at very early stages of their careers. Stagnation was not an uncommon side effect and fifteen years represents more than half an average career span. That key requirement to develop library leaders identified in the Hernon, Powell, and Young study (i.e., "a local environment that is nurturing and offers guidance and opportunities to grow and gain new and varied experiences" ${ }^{11}$ ) was absent.

For those exceptional positions that had to be filled, internal candidates were selected, sometimes with little or no managerial training and/or aptitudes. There was little new blood entering aca- 
demic libraries, when, as CREPUQ figures show, between 1980 and 1999, professional positions decreased by 30.7 percent. $^{12}$ If an external candidate had to be hired, this was more often than not on a part-time or full-time, contractual basis. It was not uncommon in the mid-1980s for professional librarians following graduation from library school to wait four or five years before landing a permanent position in an academic library. Academic libraries were closed shops. (See table 1.)

In 19 years, professional positions in Quebec academic libraries diminished from 486 to 337. Between 1995 and 1999 , the numbers diminished from 396 to 337 .

Coaching and training, usually gratifying tasks in themselves, often became onerous, time-consuming "impositions" for academic librarians because the only ones being trained were part-time or student librarians who would leave the library as soon as their contracts ended or when a permanent position became available elsewhere. Long-term mentoring, counseling, and sponsoring became obsolete in academic libraries. Those very crucial retention components-orientation, mentoring, communication, training, leadership, and job enrichment opportunities-disappeared in the flurry of daily working life.

\section{Results}

Many academic librarians have labored for the first fifteen to twenty years of their

\begin{tabular}{|lc|}
\hline \multicolumn{2}{|c|}{ TABLE 1 } \\
\multicolumn{2}{|c|}{$\begin{array}{c}\text { General Statistics of Quebec } \\
\text { University Libraries }\end{array}$} \\
\hline \hline \multicolumn{2}{|c}{ Professional Personnel } \\
\hline $1980 / 81$ & 486.8 \\
$1985 / 6$ & 459.8 \\
$1990 / 91$ & 402.3 \\
$1995 / 96$ & 396.2 \\
$1996 / 97$ & 392.2 \\
$1998 / 99$ & 381.4 \\
$1999 / 00$ & 337.3 \\
\hline
\end{tabular}

professional careers without chances for advancement into progressively responsible positions, in libraries where little, if any, new blood was likely and where annual cuts to acquisitions budgets were the norm. Inevitably, academic libraries could not affect so-called healthy organizational structures in terms of staffing levels, where, ideally, one has a breakdown of 20 percent of senior staff with many years' experience, 20 percent of (relative) newcomers, and 60 percent with a wide range of and varied professional experience.

Extremes are always problematic. (Elementary and high schools have experienced similar problems. In one Montreal elementary school last fall, fifteen out of eighteen teachers had less than three years' experience.) It is the same syndrome: Long decades with no new teachers, and then, in two or three years, all the invaluable experience disappears with massive retirements. Despite unparalleled advances in technology providing quick and easy access to information for users, academic libraries have lived through a long, dry season for fifteen years. Now, with the babyboomer cohort heading for retirement, the first loss for academic libraries will be in terms of numbers. Without a pool of potential replacements with administration experience, senior administration jobs will remain vacant and there will be fierce competition with other institutions to fill vacancies. This is regrettable because great strides have been accomplished in cooperation and resource sharing among academic research libraries.

But with the departure of the older baby boomers, a serious collective loss is imminent for academic libraries. That is the sudden loss of the invaluable experience and expertise of staff acquired over several decades.

Quebec hospitals learned a bitter lesson a few years ago when hordes of experienced surgical and emergency room nurses availed themselves of attractive early-retirement packages offered to them as cost-cutting measures. The sweet deal was a short-sited road to disaster, particularly for emergency room and surgical 
units, where jobs went crying for months. A similar situation could be felt in academic libraries.

Faculty also are at risk of facing similar problems, where entire departments could be wiped out in three to five years. To counter this potential problem, senior university administrators are openly encouraging deans to consider offering bonuses to certain faculty to remain at the university, even if they have reached normal retirement age, to avoid hiring exclusively newly graduated faculty (to prevent the same problem from recurring when they reach retirement age) and to carefully plan for an ideal mix of age levels of faculty, avoiding, whenever possible, that more than 20 percent of faculty in a given department be born in the same decade. Although these may seem extreme measures, the thought process and the planning exercise are indeed very sound.

\section{Conclusion}

It is important to remember that academic libraries will never manage themselves. Printed or electronic sources can be stocked anywhere. It will always be the professionalism of the staff who animate the contents and transform data into knowledge for users, who in turn transform such into wisdom. In compliance with ACRL standards, academic libraries must ensure that users have the ability to "determine the nature and extent of information needed, access it ef- fectively and efficiently, evaluate it, and use it to accomplish specific purposes" and "understand the economic, legal and social issues" in order to use information "ethically and legally."13 Alta Vista, Yahoo, and Google cannot do this. The time has come for the profession to strategize for succession planning. There is no question that North America will need to import professional librarians. The ALA's recognition of international "equivalents" in its accreditation processes will not solve the problem. Library schools and professional associations have a significant role to play in ensuring that professional qualifications are not diluted in the rush to fill vacancies. The teaching profession managed admirably to "upgrade" the professional qualification of teachers despite the abject shortage in the 1950s and early 1960s. By 1965, almost all elementary schoolteachers under the age of 30 had baccalaureate degrees and the two-year teachers' college programs were discontinued. There may be a potential among nonprofessional library staff, which should be tapped. Further studies are needed. Ensuring the succession in academic libraries is as basic and vital to sound management as ensuring that equipment is in place to accommodate the ever-changing formats in which information is found. Administrators appreciate knowing "who's on first," it is now high time to assess "who's next at bat."

\section{Notes}

1. Renovating the Ivory Tower: Canadian Universities \& the Knowledge Economy. Policy Study, ed. David Laidler (Toronto: C. D. Howe Institute, 2002), 37.

2. Ibid, 1 .

3. Peter Hernon, Ronald R. Powell, and Arthur P. Young, "University Library Directors in the Association of Research Libraries: The Next Generation, Part One," College \& Research Libraries (Mar. 2001).

4. Rebecca T. Lenzini, "The Greying of the Library Profession: A Survey of Our Professional Association and Their Responses," Searcher 10, no. 7 (July/Aug. 2002). Available online from http://www.infotoday.com/searcher/jul02/lenzini.htm.

5. Concordia University Libraries. Annual Report 2001-2002.

6. McGill University Libraries' Annual Report. Retrieved May 2002 from http:// www.library.mcgill.ca/admin/reports/anrpt01.htm.

7. "Recruitment \& Retention: Toward a Strategy for the University of Manitoba Libraries," prepared by the Recruitment \& Retention Task Force, University of Manitoba Libraries, 2002.

8. CARL Statistics, Ottawa, Canadian Association of Research Libraries. 
9. Hernon, Powell, and Young, "University Library Directors in the ARL: The Next Generation," College and Research Libraries (Mar. 2001).

10. Stanley J. Wilder, "The Changing Profile of Research Library Professionals," ARL 208/ 209. Retrieved June 2002 from http://www.arl.org/newsltr.208_209/chgprofile.html.

11. Hernon, Powell, and Young, "University Library Directors in the Association of Research Libraries: The Next Generation, Part Two."

12. CREPUQ, Statistiques générales des bibliothèques universitaires québécoises (Montreal: Conférence des recteurs et des principaux des universités du Quebec).

13. ACRL, "Objectives for Information Literacy Instruction: A Model Statement for Academic Librarians." Available online from http://www.ala.org/acrl/guides/objinfolit.html. 